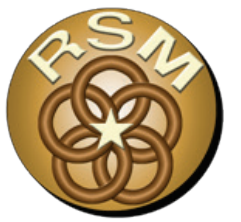

\title{
Investigation for Shoaling Reduction along the Gulf Intracoastal Waterway (GIWW) at Caney Creek, Sargent, Texas
}

By Paul Hamilton, Lihwa Lin, and Seth Jones

PURPOSE: This US Army Corps of Engineers (USACE) Regional Sediment Management (RSM) initiative considered alternatives for shoaling reduction in the Gulf Intracoastal Waterway (GIWW) in the vicinity of Caney Creek near Sargent, TX (Figure 1). Additionally, new beneficial use (BU) sites were considered along degraded islands adjacent to the GIWW with a threefold objective: increase the quality and quantity of habitat, reduce dredging cost via shorter pump distance, and reduce shoaling in the GIWW through East Matagorda Bay.

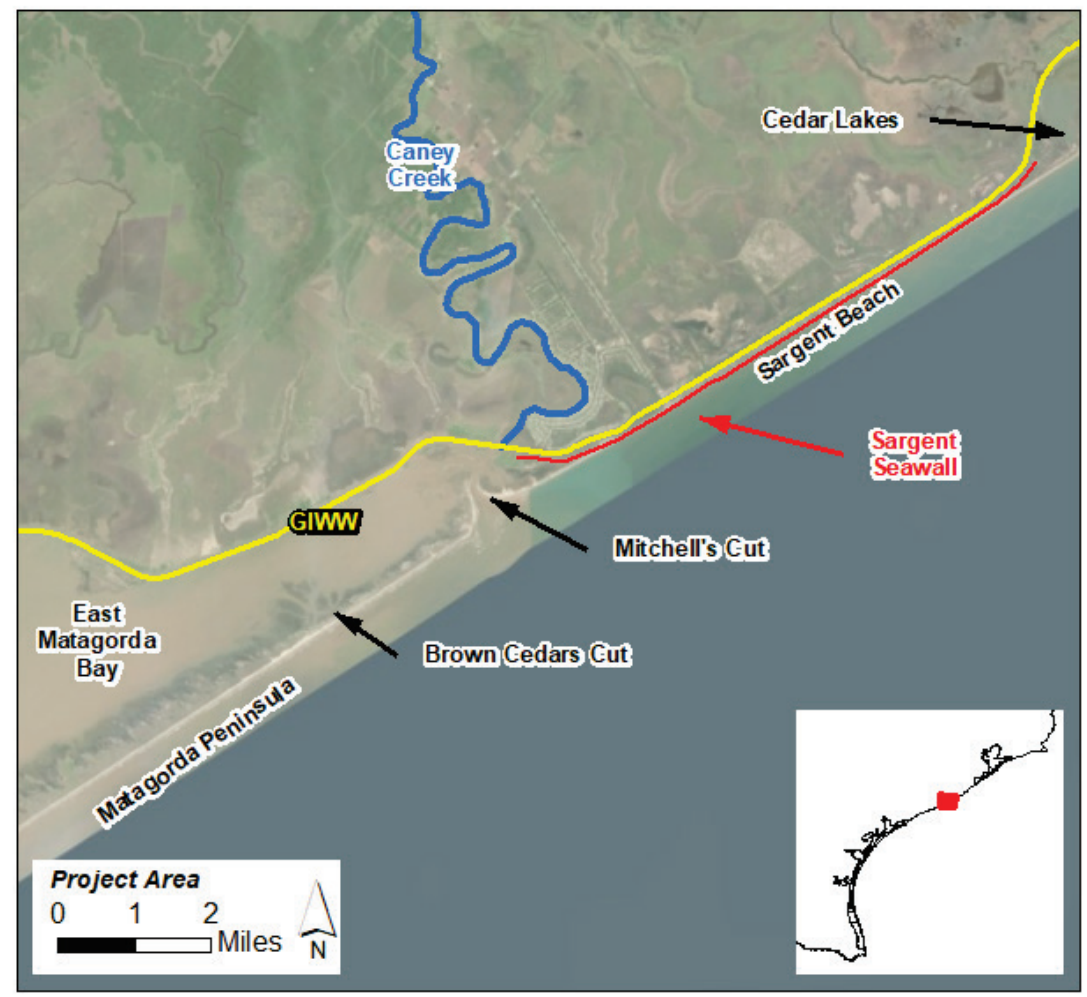

Figure 1. Study area in the vicinity of Sargent, TX.

PROJECT AREA: The project area for this initiative is the GIWW in Matagorda County, TX, near Sargent, TX (Figure 2). The primary location of interest is a shoaling hotspot in the navigation channel where both Caney Creek and Mitchell's Cut meet the channel at approximately 696+000. Caney Creek traverses approximately 155 miles ${ }^{*}$ between the larger San Bernard and Colorado Rivers before

\footnotetext{
${ }^{*}$ For a full list of the unit conversions used in this document, please refer to US Government Publishing Office Style Manual, 31st ed. (Washington, DC: US Government Publishing Office 2016), 345-7, https://www.govinfo.gov/content/pkg/GPO-STYLEMANUAL-2016/pdf/GPO-STYLEMANUAL-2016.pdf.
} 
meeting the GIWW. Mitchell's Cut is a tidal inlet connecting the Gulf of Mexico with the GIWW and East Matagorda Bay. Sargent Beach is the barrier island east of Mitchell's Cut and Matagorda Peninsula west of the Cut.

The area in and around Mitchell's Cut has experienced substantial erosion since the 1940s. Mitchell's Cut is a relatively stable inlet, though Brown Cedars Cut is an intermittently open breach in Matagorda Peninsula. Gulf shoreline change rates in Figure 3 represent long-term change to 2007 (Paine et al. 2016) and bay shoreline rates are based on the 1970s to present (Paine et al. 2014).

Given the substantial and persistent erosion along Sargent Beach, the USACE constructed a seawall along the extents of Sargent Beach in 1998 to maintain the GIWW as a sheltered waterway offset from the Gulf of Mexico. As such, there is minimal threat of breaching though there is still intent from the county and state to maintain the subaerial beach for the habitat value.

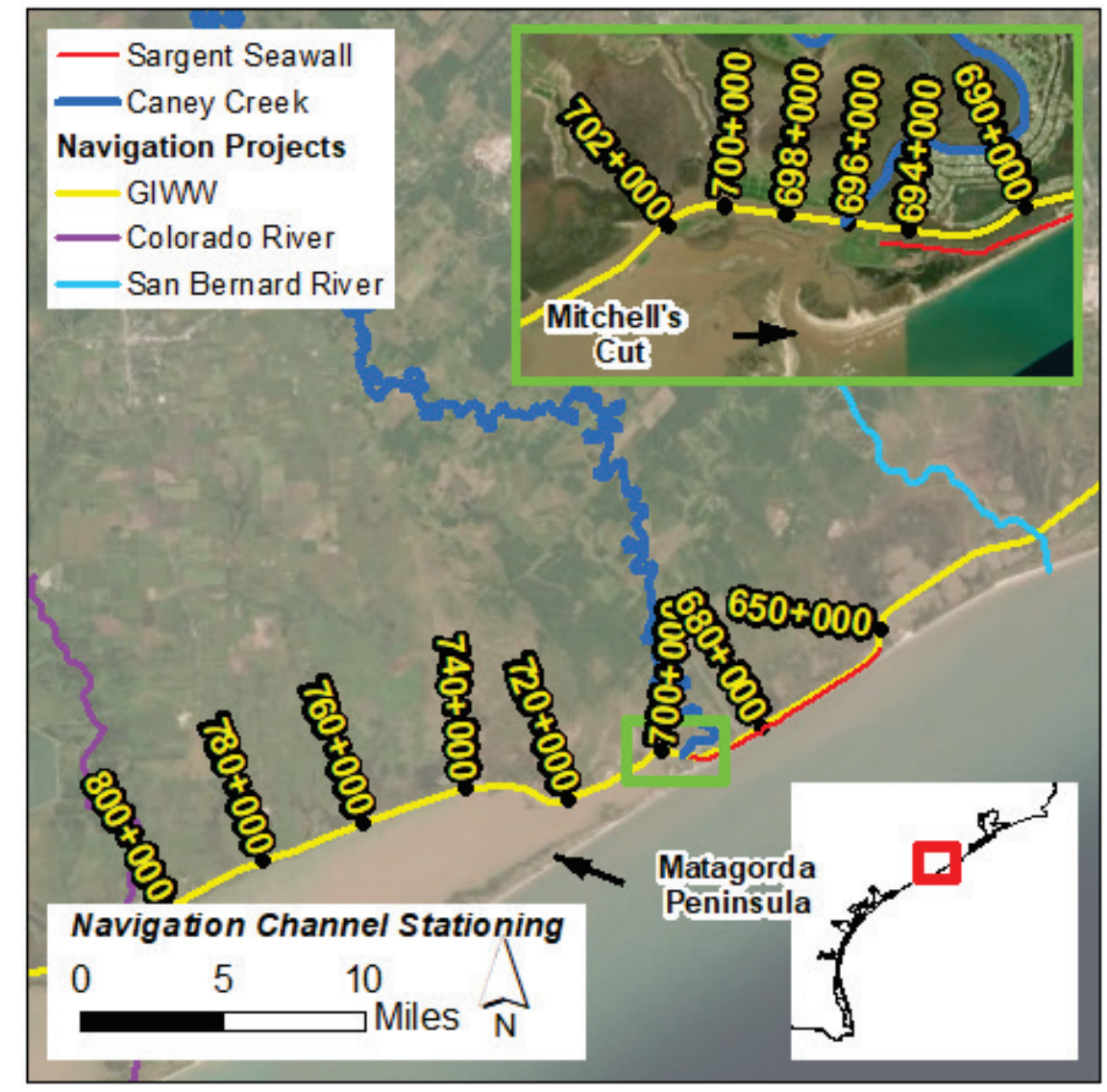

Figure 2. GIWW channel stationing. 


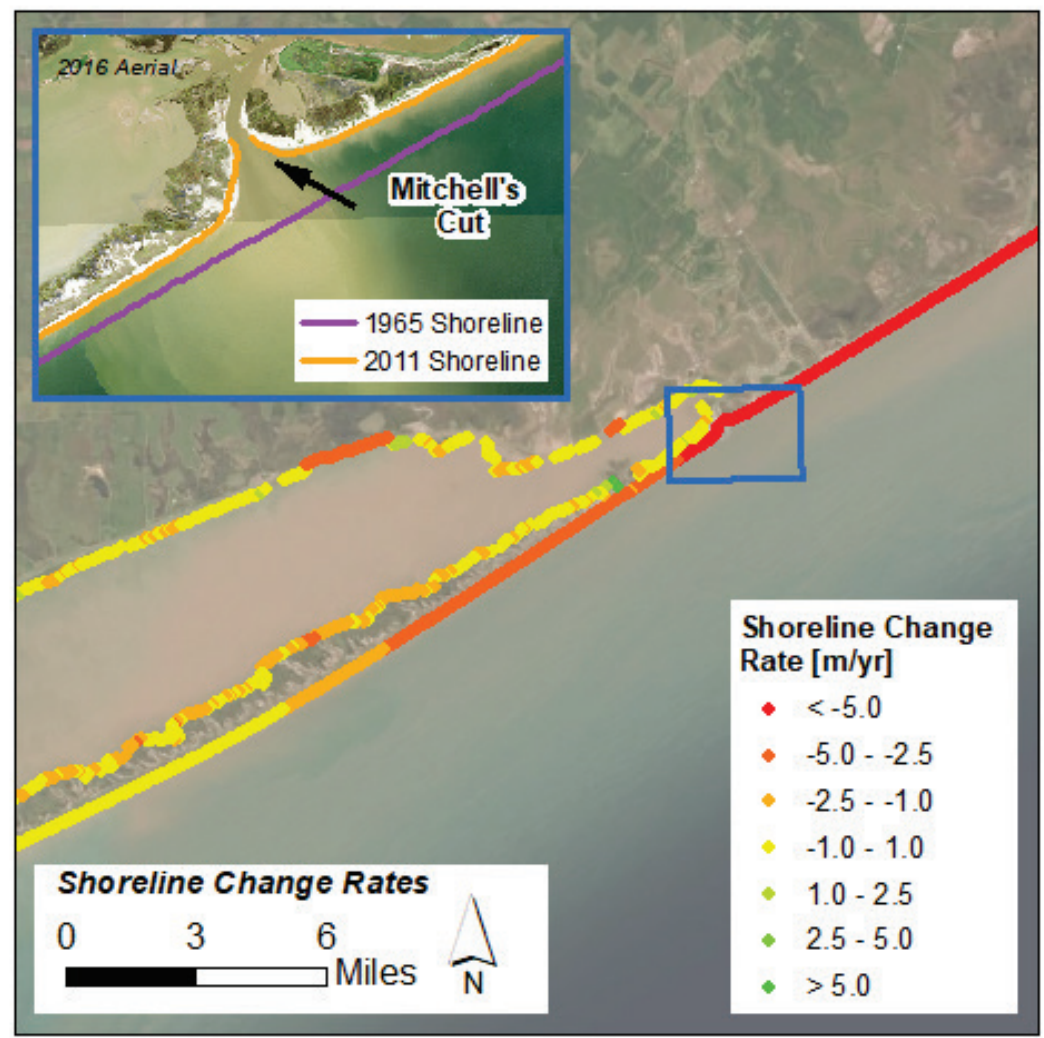

Figure 3. Shoreline change data developed by the Texas Bureau of Economic Geology.

\section{BACKGROUND AND DATA}

Dredging and Placement Information. The average annual dredging volumes for the GIWW in the vicinity of Caney Creek between $650+000$ and 800+000 are shown in Table 1. Material dredged in the vicinity of Mitchell's Cut is generally placed in the surf zone on Sargent Beach in PA 98 (Figure 4). Material from the GIWW through East Matagorda Bay is generally placed in nearby upland confined placement areas (e.g., PA 102-C, PA 104-B, PA 105-A, and PA 106).

\begin{tabular}{|ccc||}
\hline \multicolumn{3}{|c|}{$\begin{array}{l}\text { Table 1. Average annual dredging for the } \\
\text { GIWW in the vicinity of the project. }\end{array}$} \\
\hline \hline $\begin{array}{c}\text { From } \\
\text { Station }\end{array}$ & $\begin{array}{c}\text { To } \\
\text { Station }\end{array}$ & $\begin{array}{c}\text { Average Annual } \\
\text { Dredging } \\
\text { [1000s CY] }\end{array}$ \\
\hline $650+000$ & $685+000$ & 26.4 \\
$685+000$ & $690+000$ & 10.4 \\
$690+000$ & $695+000$ & 32.7 \\
$695+000$ & $700+000$ & 30.5 \\
$700+000$ & $705+000$ & 17.1 \\
$705+000$ & $800+000$ & 260.5 \\
\hline
\end{tabular}


April 2021

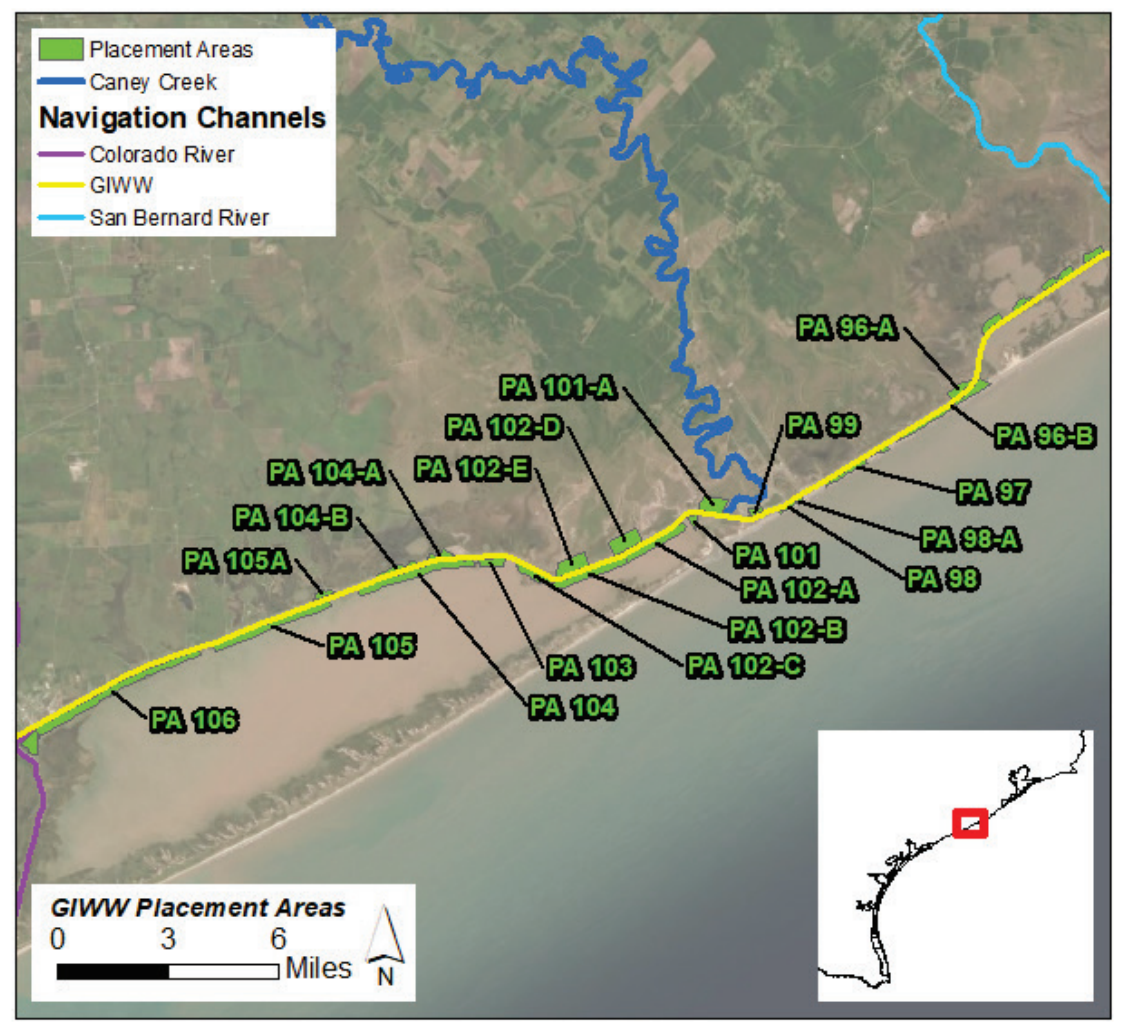

Figure 4. Dredged material placement areas for the GIWW in the project area vicinity.

Tides and Tidal Datum Information. Tidal datum information as reflected at the National Oceanic and Atmospheric Administration (NOAA) station at Sargent (\#8772985) is shown in Table 2. The Texas Coast is a microtidal environment with much of the observed water level dependent on local fluvial discharge and wind conditions.

\begin{tabular}{|llcc||}
\hline \multicolumn{3}{|l||}{$\begin{array}{l}\text { Table 2. Datum information at the NOAA station at Sargent } \\
\text { (\#8772985). }\end{array}$} & \multicolumn{2}{|c|}{} \\
\hline \hline & & $\begin{array}{c}\text { Value } \\
{[\mathrm{ft}]}\end{array}$ & $\begin{array}{c}\text { Value } \\
{[\mathrm{m}]}\end{array}$ \\
Datum & Description & 0.58 & 0.177 \\
MHHW & Mean Higher-High Water & 0.55 & 0.168 \\
MHW & Mean High Water & 0.33 & 0.101 \\
MSL & Mean Sea Level & 0.29 & 0.088 \\
MTL & Mean Tide Level & 0.02 & 0.006 \\
MLW & Mean Low Water & 0.00 & 0.000 \\
MLLW & Mean Lower-Low Water & & \\
\hline
\end{tabular}


Grain Size Data. Grain size data are available from TxSed (Texas General Land Office 2019), a statewide database managed by the Texas General Land Office (GLO) that compiles sediment data from multiple sources. Figure 5 shows the grain size characteristics in and around the study area as a function of sand content. The data shown are the surface grab samples in the TxSed database that have the gradations readily available. Additional core data are available in the area that is not shown here. The sediment along Sargent Beach is generally very fine-to-fine sand based on grab samples from the subaqueous beach landward of the first bar collected and analyzed by Rosati et al. (2013). This characterization was visually confirmed during a site visit on May 3, 2019. During the same site visit, a Ponar grab sample was collected in Caney Creek off the County Road 286 Bridge. This sediment was not sized quantitatively but could be qualitatively categorized as substantially fines with minimal sand.

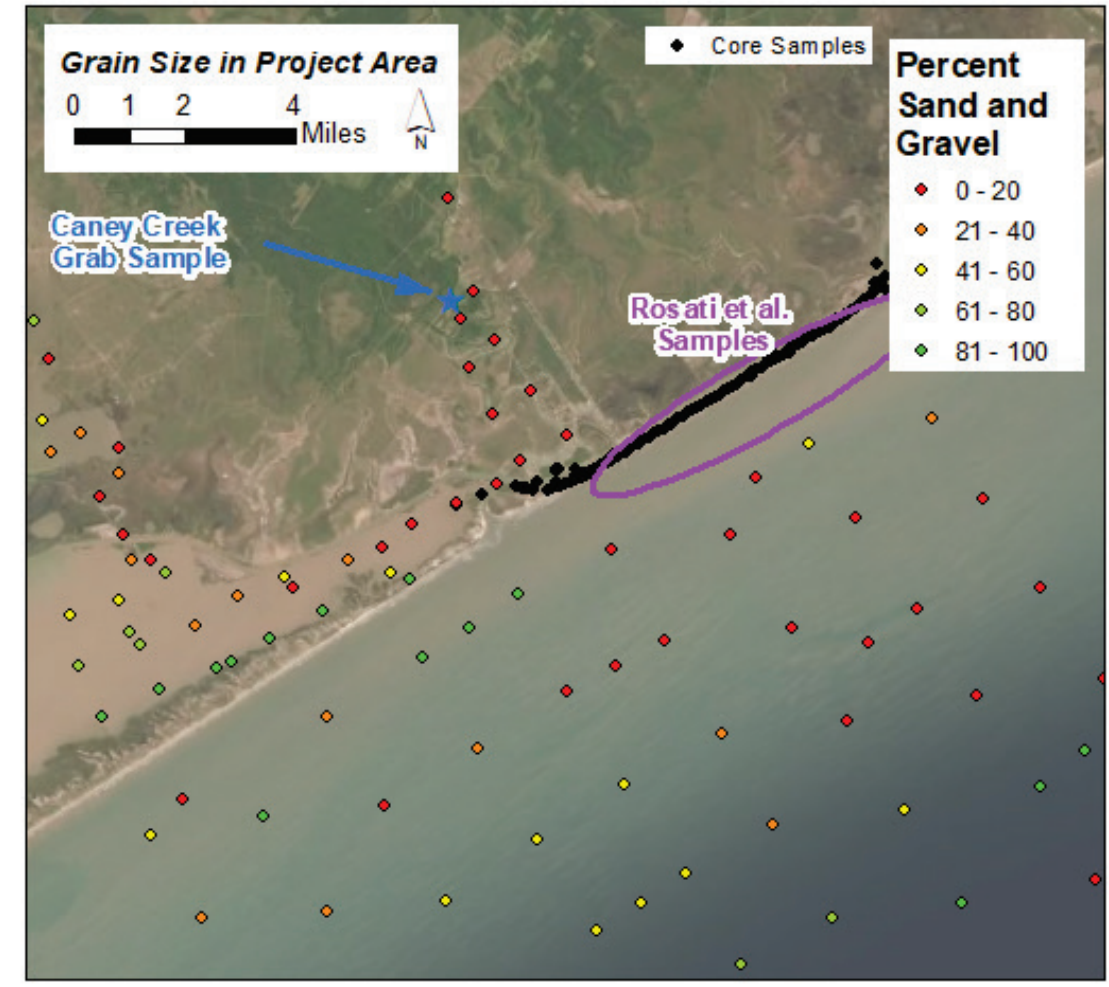

Figure 5. Grain size data in the project area from the TxSed database. The location of the Rosati et al. (2013) samples are identified along Sargent Beach and the May 3, 2019, grab samples on Caney Creek.

Meteorological and Oceanographic Data. Figure 6 shows the wind rose for meteorological data during 2018 at the Sargent NOAA station (\#8772985). Wind in the project area is predominantly from the south-southeast. The available data are not a long-term continuous dataset but appear to be an approximate representation of wind speed and direction based on comparisons with other nearby stations (e.g., NOAA station at Freeport, TX (\#8772447), approximately 20 miles east of Sargent Beach). 
April 2021

\section{METHODS}

Numerical Modeling. Existing conditions and the considered alternatives were simulated using the Coastal Modeling System (CMS). The CMS is a depth-averaged hydrodynamic and wave model well suited for the project area (i.e., coastal embayments). In addition to the flow and wave simulations, the CMS calculates sediment transport and morphologic change throughout the simulations (Demirbilek and Rosati 2011).

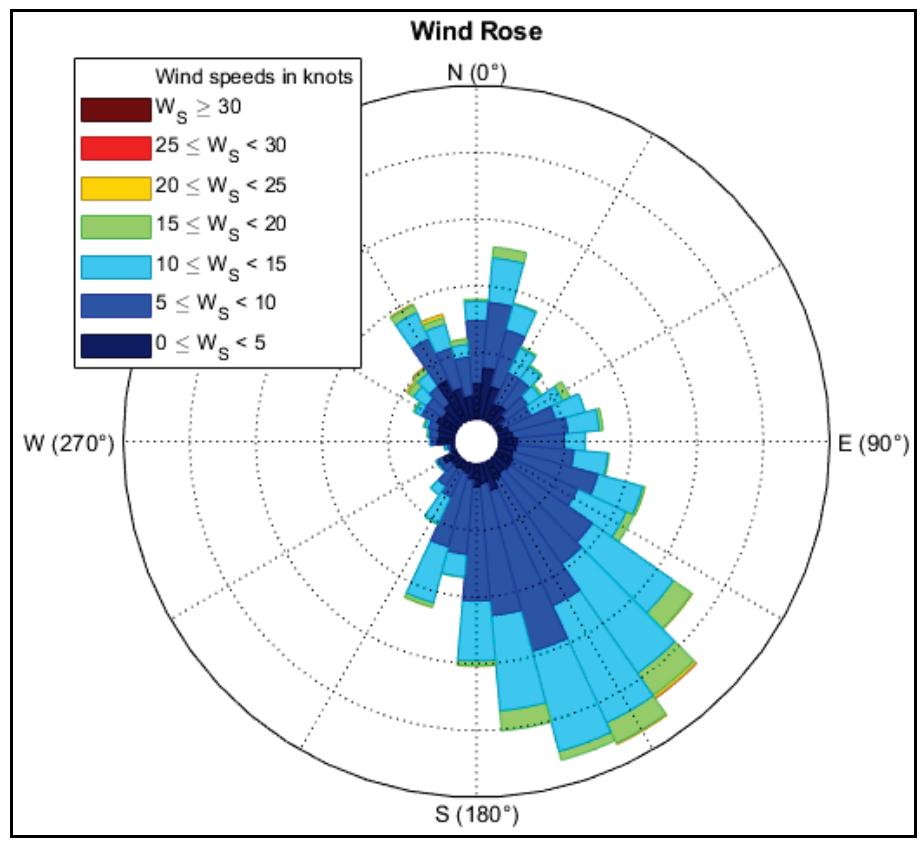

Figure 6. Wind rose based on 2018 wind data at the Sargent NOAA station (\#8772985).

The CMS model covers the East Matagorda Bay. The model domain is a rectangular area of $20 \mathrm{~km}^{*}$ $\times 40 \mathrm{~km}$ with higher cell resolution approximately $10 \mathrm{~m}$ along navigation channels and lower resolution of $100 \mathrm{~m}$ in the offshore area. The CMS model was forced at the boundary using hydrodynamic outputs from a regional Advanced Circulation (ADCIRC) model ( $\mathrm{https}$ ://adcirc.org/) covering both East Matagorda Bay and Matagorda Bay. Figures 7 and 8 show the regional ADCIRC mesh and local CMS grid. The calibration and model setup of ADCIRC and CMS models in the Matagorda Bay region were based on several previous studies ${ }^{\dagger *}$ (Kraus et al. 2006; Maynord et al.

\footnotetext{
${ }^{*}$ For a full list of the spelled-out forms of the units of measure used in this document, please refer to US Government Publishing Office Style Manual, 31st ed. (Washington, DC: US Government Publishing Office 2016), 248-52, https://www.govinfo.gov/content/pkg/GPO-STYLEMANUAL-2016/pdf/GPO-STYLEMANUAL-2016.pdf.

${ }^{\dagger}$ Lin, L. Unpublished letter report. Flood Relief Project - Evaluation of a Proposed Culvert under Highway FM 2031, Matagorda County, Texas. Vicksburg, MS: US Army Engineer Research and Development Center.

*Lin, L., M. S. Islam, and T. E. White. Unpublished letter report. Hydrodynamic and Salinity Modeling for Matagorda Ship Channel (MSC) Channel Improvement Project. Vicksburg, MS: US Army Engineer Research and Development Center.
} 
2011). Comparison to water level, current, and wave were not possible as there were no such measurements in the model area. Model channel bathymetry was updated by recent hydrographic surveys in 2017 and 2018 (http://navigation.usace.army.mil/Survey/Hydro). The modeling was conducted for 1-year simulation of May 2016 to April 2017 when two complete condition surveys in the GIWW were available for model calibration of channel shoaling rate. Model forcings included field measurements of river influx, offshore incident waves, coastal water level variation, and surface winds for wind-wave generation in the bay system ${ }^{*}$ (Kraus et al. 2006). A median grain size of 0.1 $\mathrm{mm}$ (D50) was used in the model sediment transport and morphology change.

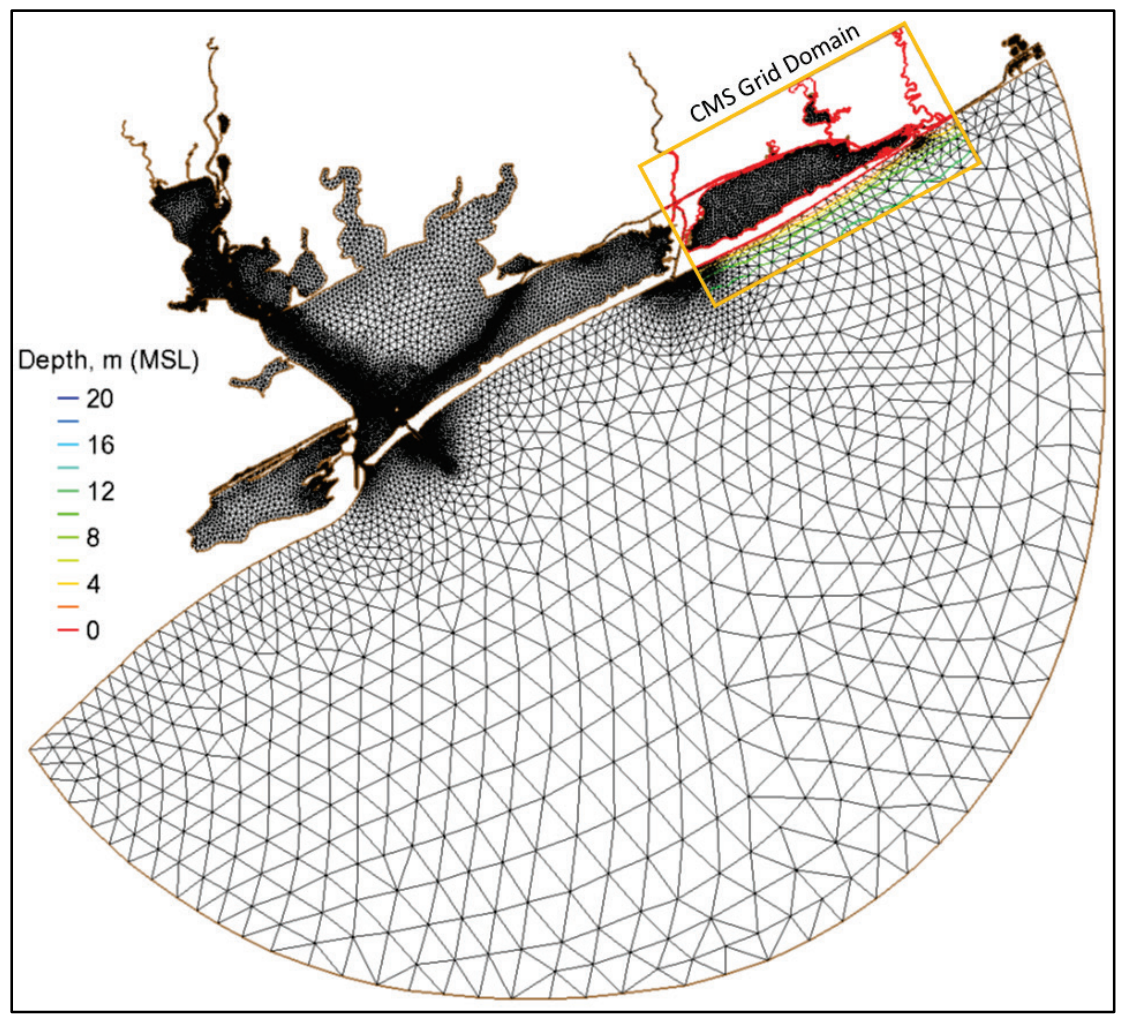

Figure 7. ADCIRC Mesh and CMS model domain.

${ }^{*}$ Lin, L., M. S. Islam, and T. E. White. Unpublished letter report. Hydrodynamic and Salinity Modeling for Matagorda Ship Channel (MSC) Channel Improvement Project. Vicksburg, MS: US Army Engineer Research and Development Center. 


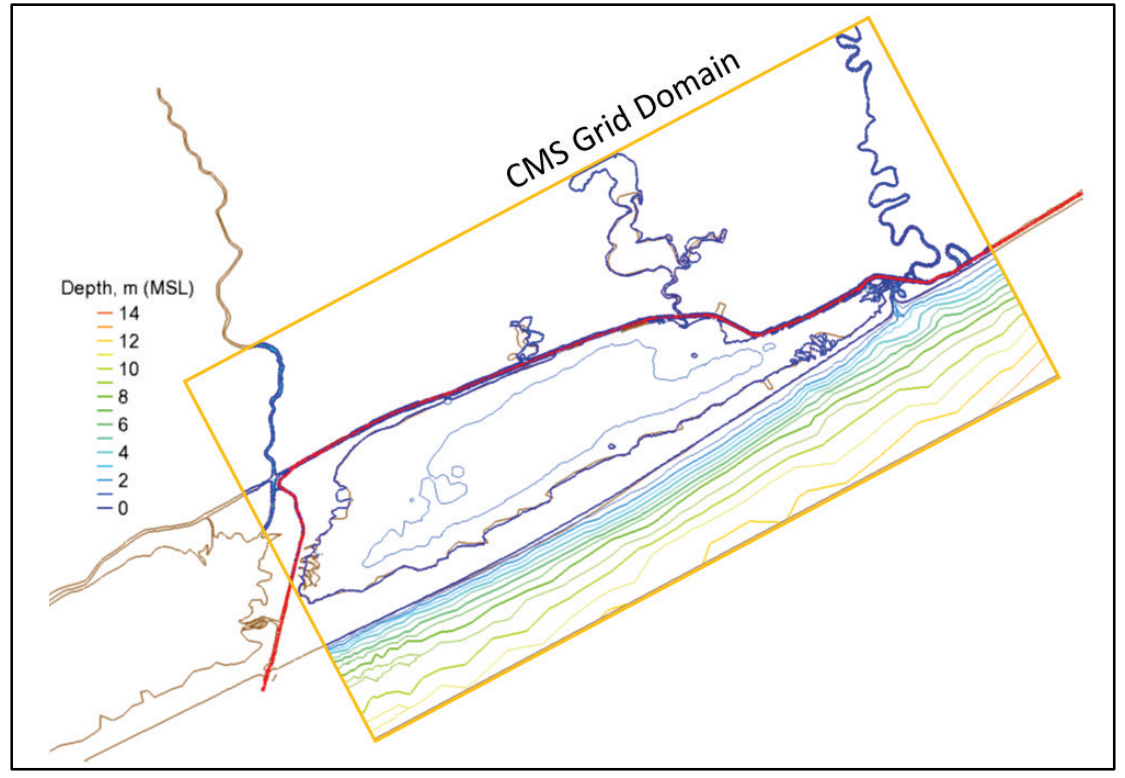

Figure 8. Local CMS model domain with recent channel survey area (red line).

Sediment Budget Analysis. Thomas and Dunkin (2012) developed a conceptual sediment budget for the gulf shoreline used herein without amendment. Additionally, a sediment budget was developed for the entirety of the Texas Coast as a part of the Coastal Texas Protection and Restoration Feasibility Study (USACE 2018). This sediment budget included the Thomas and Dunkin (2012) for the gulf shoreline and added navigation dredging and bay transport insofar as data were available for each. The dredging information used as a part of the comprehensive coastal Texas sediment budget included long reaches such that the spatial resolution was coarse. Dredging records were more rigorously considered to increase detail in the project area for this effort.

Based on the sediment budget analysis, the primary sediment source to the GIWW shoaling hotspot is most likely Sargent Beach sediments transported through Mitchell's Cut. The sediment yield from Caney Creek is not known given the lack of stream gaging or sediment transport data collection. However, in terms of sediment contribution to the problematic shoal, evidence supports the gulf-side source conclusion, namely its position nearer Mitchell's Cut than Caney Creek and that its composition is primarily sand which is found on Sargent Beach rather than in Caney Creek. As previously noted, the material in Caney Creek is primarily fine based on the grab sample collected.

Another potential sediment source to the bay system and navigation channel is lateral input from bay-shoreline erosion. Historical aerials since 1996 indicate that the emergent islands neighboring Mitchell's Cut have been relatively stable and are likely not substantial contributors to the problematic shoal near the inlet. Away from the area near Mitchell's cut, shoreline erosion is a potentially large contributor of material to the GIWW. Paine et al. (2014) have shown erosion rates along the perimeter of East Matagorda Bay of up to $3 \mathrm{~m} / \mathrm{year}$ (Figure 3). Additionally, because of the degraded islands that once sheltered the GIWW from the open bay, there is an open pathway for sediment from within the bay to be deposited in the navigation channel. 
ALTERNATIVES CONSIDERED: Five alternatives, in addition to no action, were considered as shoaling reduction measures in the project area. The no action alternative, also denoted as Alternative 0, represents a continuation of existing conditions into the future. The potential construction alternatives fall into three conceptual categories: (1) reduction of sediment transport from the beach, (2) interception of sediment transport at or near the navigation channel, and (3) island stabilization to improve ecosystem quantity and quality that additionally intercepts bay sediment transport. The measures are shown as modeled alternatives in Figure 9.

Alternative 1 (Figure 9A) consists of construction of segmented offshore breakwaters along Sargent Beach east of Mitchell's Cut. It also consists of construction of BU sites along the GIWW in East Matagorda Bay. During the course of considering the project site, the USACE team learned that the GLO intends to work with Matagorda County to implement the segmented offshore breakwaters included in this alternative through the Coastal Erosion Planning and Response Act. The County is also considering the pursuit of FEMA Hazard Mitigation Grant money to implement Sargent Beach measures. The island restoration concept is a semi-confined BU site with a revetment on the navigation channel side and open to the bay side. This strategy mimics those outlined in Hamilton et al. (2019) for the Channel to Victoria would be appropriate given the similarity of environment.

Alternative 2 (Figure 9B) mimics Alternative 1 but includes an additional segment of island restoration. Alternative 3 (Figure 9C) consists of construction of segmented offshore breakwaters along the beach west of Mitchell's Cut. Alternative 4 (Figure 9D) consists of dredging a sediment trap within the GIWW (i.e., additional depth within the channel template). Alternative 5 (Figure 9E) consists of dredging a sediment trap offset from the GIWW in Mitchell's Cut. 
ERDC/TN RSM-21-1

April 2021
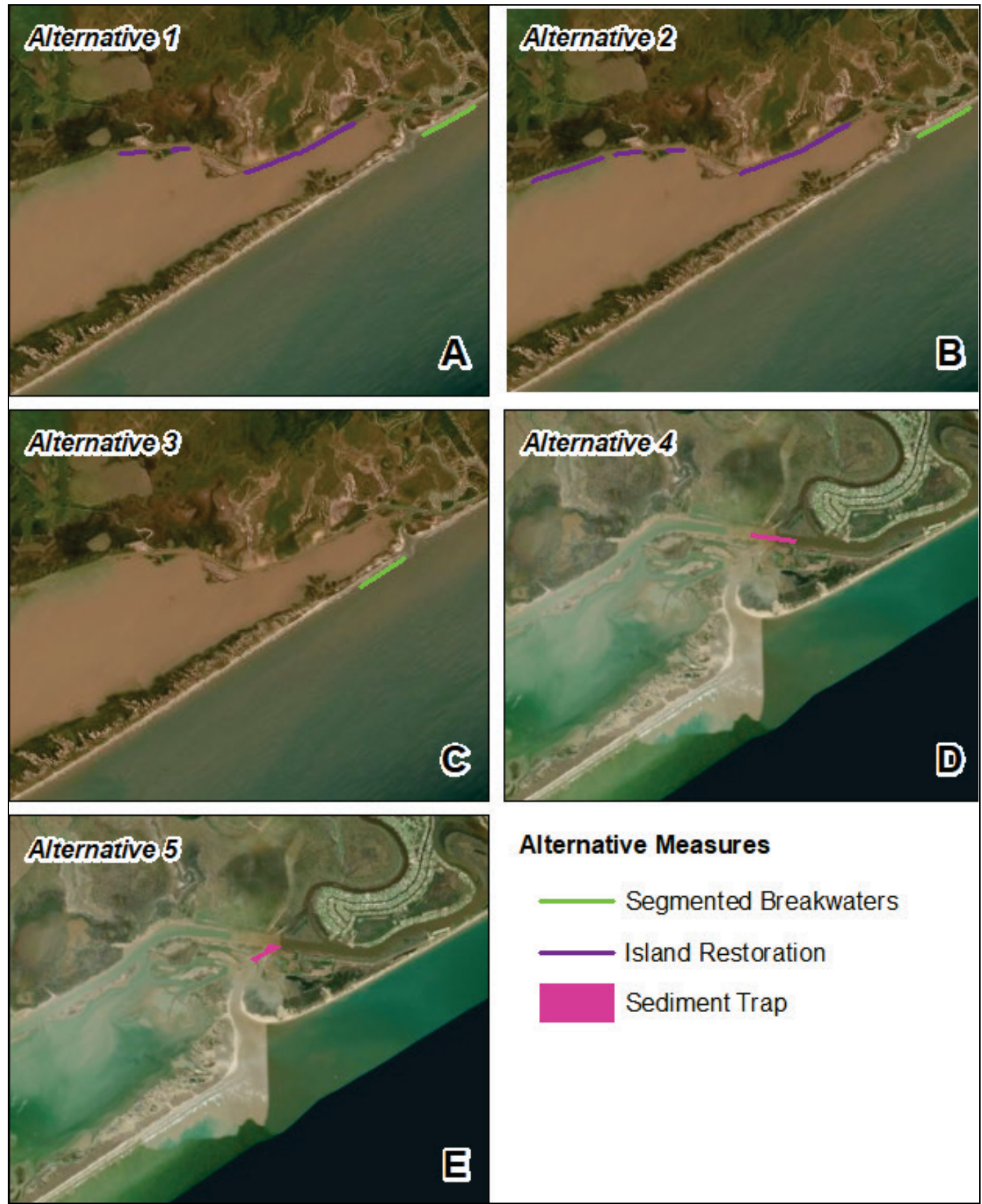

Alternative Measures

— Segmented Breakwaters

_ Island Restoration

Sediment Trap

Figure 9. Alternatives modeled in the project area. 
ALTERNATIVES ANALYSIS: Existing conditions and considered alternatives were simulated using the CMS model previously discussed (1-year simulation for May 2016 to April 2017). The effects on shoaling were reported in four analysis reaches (Figure 10). Though the alternatives combine gulf shoreline measures and island restoration in the bays, these are considered separable elements in terms of analysis and implementation. Segment C-D is considered indicative of the performance of measures meant to manage Gulf of Mexico sediments and segments A-B and B-C of performance of measures in the bay. Costs were not estimated as a part of this RSM initiative, though that would need to be done ahead of alternative selection.

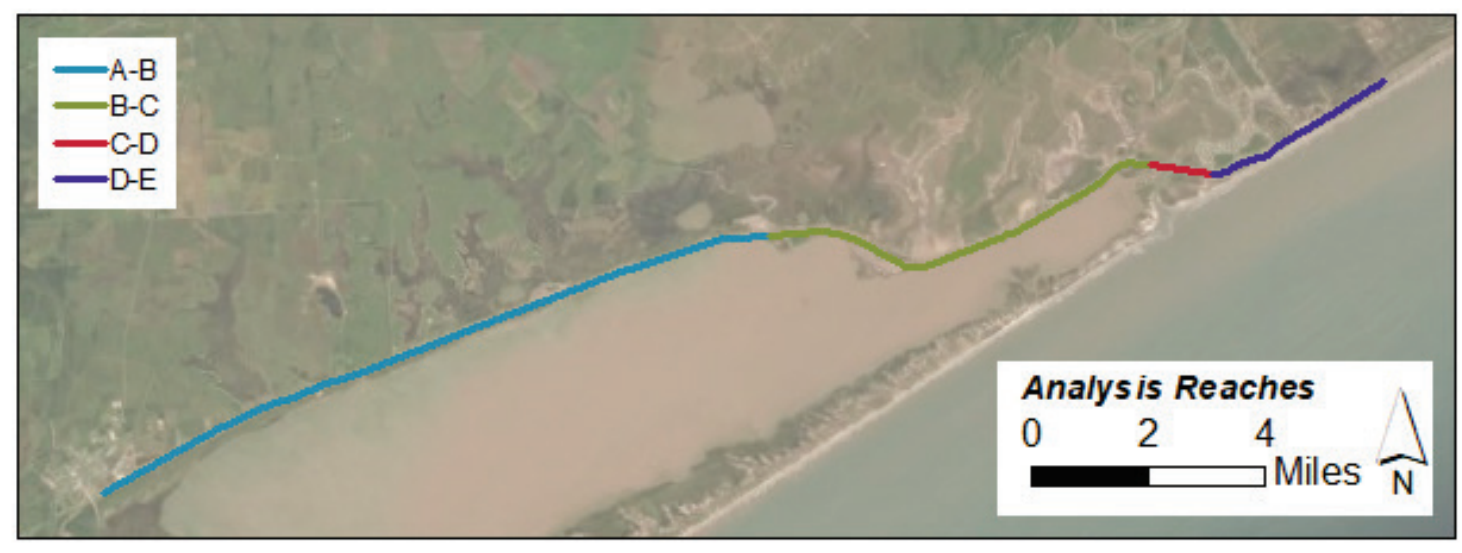

Figure 10. Analysis reaches for the CMS outputs.

Table 3 shows the results of the CMS simulations in terms of morphologic change in each analysis reach for existing conditions and each alternative. All circumstances have minimal change in segment $\mathrm{D}-\mathrm{E}$, though there is a minimal dredging requirement there. This outcome provides evidence that the alternatives would not have adverse impacts in the GIWW landward of Sargent Beach.

The island restoration measures were effective in reducing shoaling in the reaches through East Matagorda Bay. The additional benefit of constructing the BU sites is that the sites would reduce pump distances relative to the upland confined placement areas currently utilized.

\section{Table 3. Simulated difference in shoaling volume in the analysis reaches for existing conditions and proposed alternatives. Volumes are in cubic meters and "\% red." represents the percent reduction in shoaling during the simulation. Note that negative numbers for percent reduction denote increases in shoaling over baseline conditions.}

\begin{tabular}{|c|c|c|c|c|c|c|c|c|c|c|c|}
\hline \multirow[b]{2}{*}{ Section } & \multirow{2}{*}{$\begin{array}{l}\text { Ex. Cond. } \\
\text { Volume }\end{array}$} & \multicolumn{2}{|c|}{ Alt 1} & \multicolumn{2}{|c|}{ Alt 2} & \multicolumn{2}{|c|}{ Alt 3} & \multicolumn{2}{|c|}{ Alt 4} & \multicolumn{2}{|c|}{ Alt 5} \\
\hline & & Volume & $\%$ red. & Volume & $\%$ red. & Volume & $\%$ red. & Volume & $\%$ red. & Volume & $\%$ red. \\
\hline$A-B$ & 255,020 & 217,210 & 15 & 109,290 & 57 & 254,790 & 0 & 254,280 & 0 & 255,240 & 0 \\
\hline$B-C$ & 207,950 & 52,220 & 75 & 49,040 & 76 & 208,150 & 0 & 211,750 & -2 & 222,050 & -7 \\
\hline$C-D$ & 112,570 & 107,890 & 4 & 106,910 & 5 & 129,360 & -15 & 34,250 & 70 & 30,830 & 73 \\
\hline D-E & 20,660 & 20,140 & 3 & 18,760 & 9 & 21,370 & -3 & 23,600 & -14 & 22,040 & -7 \\
\hline
\end{tabular}


For the gulf shoreline measures, the modeling did not simulate shoaling reduction at the Mitchell's Cut hotspot. This ran contrary to the expectations based on modeling done by Thomas and Dunkin (2012) and Rosati et al. (2013) that showed shoreline accretion to the east of Mitchell's Cut on Sargent Beach with segmented shore-parallel, detached breakwaters. The sediment trap alternatives were both effective at reducing shoaling volumes in the Mitchell's Cut hotspot. To preserve the shoaling reduction benefits, the traps would need to be maintained with the navigation channel.

SUMMARY: The alternative measures considered herein, with the exception of nearshore breakwaters west of Mitchell's Cut, would likely benefit the GIWW navigation project. Construction of BU sites along the south of the GIWW navigation channel could offer a degree of shoaling reduction based on the CMS simulations. The sites would have the extra advantage of providing habitat benefit in East Matagorda Bay. These measures were cost effective when evaluated for the Channel to Victoria (Hamilton et al. 2019). PA 102-A and PA 102-B are degraded islands that should be first evaluated further for construction and usage; PA 104 would be the next that should be evaluated. A cost analysis needs to be done ahead of implementation of any of these alternatives by the USACE.

For the Mitchell's Cut area, given the intended construction of the proposed nearshore breakwater feature by the county and GLO, the most prudent strategy for the GIWW navigation project is to monitor the effects of those structures on the shoaling hotspot. The modeling did not show shoaling reduction, though CMS did not simulate the without-project beach erosion, the reduction of which would be the source of any navigation benefits. There is the potential that the implementation of the non-federal project along Sargent Beach could benefit the GIWW.

In the interim, the sediment trap measures could provide some relief in terms of frequency of dredging, though the total volume would likely be similar. If monitoring following the breakwaters along Sargent Beach reveals some reduced shoaling, a sediment trap would be a good alternative to mitigate some residual transport.

ADDITIONAL INFORMATION: This USACE Regional Sediment Management technical note (RSM-TN) was prepared by Paul Hamilton and Seth Jones, USACE Galveston District (SWG), and Lihwa Lin, US Army Engineer Research and Development Center, Coastal and Hydraulics Laboratory. This study was conducted as an activity of the USACE RSM Program, a Navigation Research, Development, and Technology portfolio program administered by Headquarters USACE. Additional information pertaining to the SWG RSM investigations can be obtained from Paul Hamilton (Paul.B.Hamilton@usace.army.mil), the SWG RSM Point of Contact. For information pertaining to the National RSM Program, please consult the RSM website (http://rsm.usace.army.mil), or contact the USACE RSM Program Manager, Katherine E. Brutsché (katherine.e.brutsche@usace.army.mil). For further information pertaining to this RSM-TN, please contact Paul Hamilton. 
This RSM-TN should be cited as follows:

Hamilton, Paul, Lihwa Lin, and Seth Jones. 2021. Investigation for Shoaling Reduction along the Gulf Intracoastal Waterway (GIWW) at Caney Creek, Sargent, Texas. ERDC/TN RSM-21-1. Vicksburg, MS: US Army Engineer Research and Development Center. http://dx.doi.org/10.21079/11681/40359

\section{REFERENCES}

Demirbilek, Z., and J. Rosati. 2011. Verification and Validation of the Coastal Modeling System: Executive Summary. ERDC/CHL TR-11-10. Vicksburg, MS: US Army Engineer Research and Development Center.

Hamilton, P. B., L. Lin, S. Howard, A. Burgin, and B. Crawford. 2020. Design Considerations for Beneficial Use Sites along the Channel to Victoria, Calhoun County, Texas. ERDC/TN RSM-20-2. Vicksburg, MS: US Army Research and Development Center.

Kraus, N. C., L. Lin, B. K. Batten, and G. L. Brown. 2006. Matagorda Ship Channel, Texas: Jetty Stability Study. ERDC/CHL TR-06-7. Vicksburg, MS: US Army Engineer Research and Development Center.

Maynord, S. T., L. Lin, N. C. Kraus, D. W. Webb, G. Lynch, R. E. Wahl, D. A. Leavell, D. E. Yule, and J. B. Dunbar. 2011. Risks to Navigation at the Matagorda Ship Channel Entrance, Texas, Phase 2: Evaluation of Significant Risk Factors. ERDC/CHL TR-11-8. Vicksburg, MS: US Army Engineer Research and Development Center.

Paine, J. G., T. Caudle, and J. Andrews. 2014. Shoreline Movement along the Texas Gulf Coast, 1930s to 2012. Bureau of Economic Geology report prepared for Texas General Land Office. https://www.glo.texas.gov/coastalgrants/documents/grant-project/1563-final-rpt.pdf

Paine, J. G., T. Caudle, and J. Andrews. 2016. Shoreline Movement in the Copano, San Antonio, and Matagorda Bay Systems, Central Texas Coast, 1930s to 2010s. Bureau of Economic Geology report prepared for Texas General Land Office. http://www.beg.utexas.edu/files/content/beg/research/bayShorelineChange_20161114.pdf

Rosati III, J., A. E. Frey, and R. C. Thomas. 2013. Erosion Control and Environment Restoration Plan Development: Matagorda County, Texas: Phase 2: Preliminary Design. ERDC/CHL TR-12-11. Vicksburg, MS: US Army Engineer Research and Development Center.

Texas General Land Office. 2019. TxSed Database. http://gisweb.glo.texas.gov/txsed/index.html

Thomas, R., and L. Dunkin. 2012. Erosion Control and Environment Restoration Plan Development, Matagorda County, Texas: Phase 1: Preliminary Investigation. ERDC/CHL TR-12-11. Vicksburg, MS: US Army Engineer Research and Development Center.

USACE (US Army Corps of Engineers). 2018. Coastal Texas Protection and Restoration Feasibility Study: Draft Integrated Feasibility Report and Environmental Impact Statement. USACE - Galveston District.

NOTE: The contents of this technical note are not to be used for advertising, publication, or promotional purposes. Citation of trade names does not constitute an official endorsement or approval of the use of such products. 